WSRC-RP-95-831, Rev. 1.2, Fina/

\title{
Statement of Basis/Proposed Plan for the F-Area Burning/Rubble Pits (231-F, 231-1F, and 231-2F)
}

by

E. Palmer

Westinghouse Savannah River Company

Savannah River Site

Aiken, South Carolina 29808

DOE Contract No. DE-AC09-89SR18035

This paper was prepared in connection with work done under the above contract number with the U. S.

Department of Energy. By acceptance of this paper, the publisher and/or recipient acknowledges the U. S. Government's right to retain a nonexclusive, royalty-free license in and to any copyright covering this paper, along with the right to reproduce and to authorize others to reproduce all or part of the copyrighted paper.
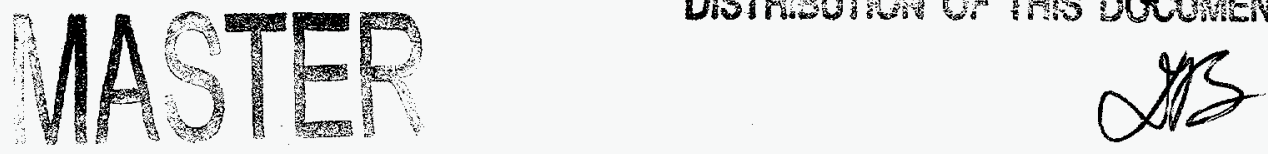
United States Department of Energy

Savannah River Site

\section{Statement of Basis/Proposed Plan for the F-Area Burning/Rubble Pits (231-F, 231-1F, and 231-2F) (U)}

WSRC-RP-95-831

Revision 1.2

August 1996 


\section{DISCLAIMER}

This report was prepared as an account of work sponsored by an agency of the United States Government. Neither the United States Government nor any agency thereof, nor any of their employees, makes any warranty, express or implied, or assumes any legal liability or responsibility for the accuracy, completeness, or usefulness of any information, apparatus, product, or process disclosed, or represents that its use would not infringe privately owned rights. Reference herein to any specific commercial product, process, or service by trade name, trademark, manufacturer, or otherwise does not necessarily constitute or imply its endorsement, recommendation, or favoring by the United States Government or any agency thereof. The views and opinions of authors expressed herein do not necessarily state or reflect those of the United States Government or any agency thereof.

This report has been reproduced directly from the best available copy.

Available to DOE and DOE contractors from the Office of Scientific and Technical Information, P.O. Box 62, Oak Ridge, TN 37831; prices available from (615) 576-8401.

Available to the public from the National Technical Information Service, U.S. Department of Commerce; 5285 Port Royal Road, Springfield, VA 22161. 


\section{DISCLAIMER}

Portions of this document may be illegible electronic image products. Images are produced from the best available original document. 


\section{Table of Contents}

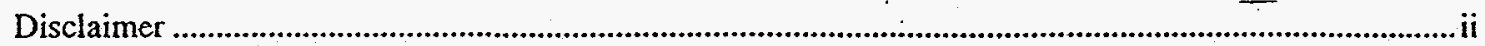

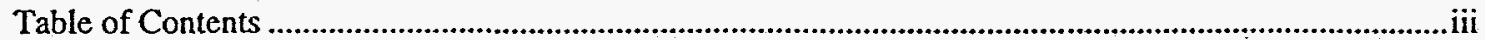

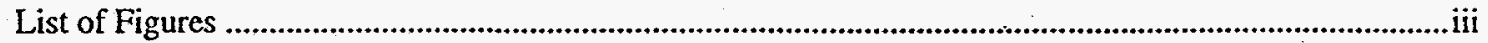

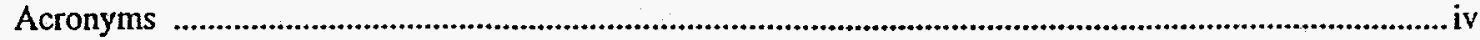

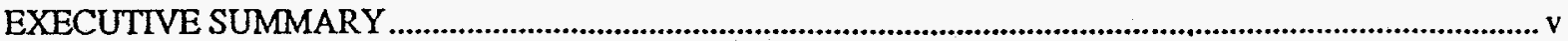

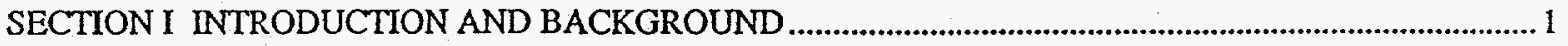

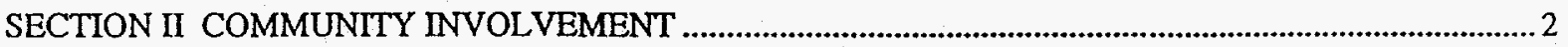

SECTION III SCOPE AND ROLE OF OPERABLE UNIT (RESPONSE ACTION) WITHIN

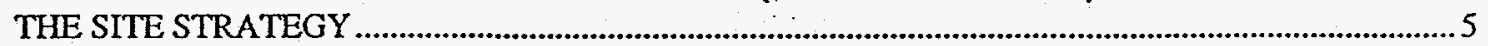

SECTION IV MEDIA SPECIFIC OPERABLE UNIT - THE FBRP ............................................................5

Section IV.A Unit Description, History, and Media Assessment ......................................................5

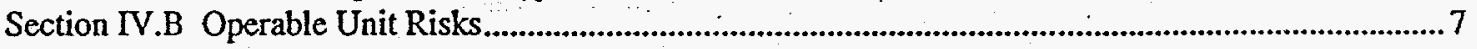

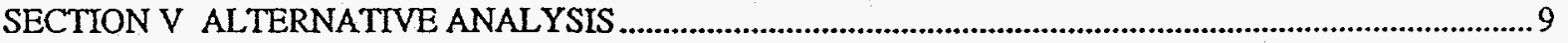

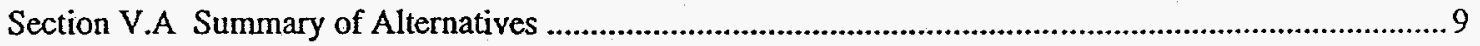

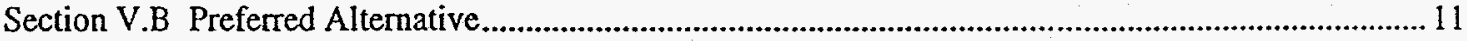

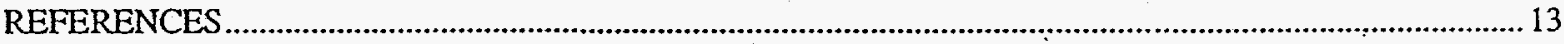

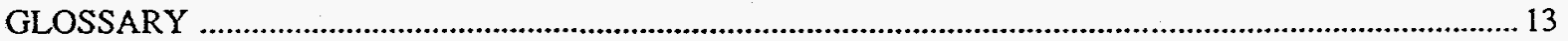

\section{List of Figures}

Figure 1 Location of the F-Area Buming/Rubble Pits (231-F and 231-1F) and Rubble Pit (231-2F) in Relation to Major Savannah River Site Facilities

Figure 2 Topographic and Water Table Potentiometric Map of the F-Area Burning/Rubble Pits (231-F and 231-1F) and Rubble Pit (231-2F) " $:$ 


\section{Acronyms}

$\begin{array}{ll}\text { ARAR } & \text { Applicable, or Relevant and Appropriate Requirements } \\ \text { BRA } & \text { Baseline Risk Assessment } \\ \text { CERCLA } & \text { Comprehensive Environmental Response, Compensation, and Liability Act, 1980 } \\ \text { DOE } & \text { U. S. Department Of Energy } \\ \text { EPA } & \text { U. S. Environmental Protection Agency } \\ \text { FBRP } & \text { F-Area Burning/Rubble Pits (generally including Rubble Pit 231-2F) } \\ \text { PCB-1254 } & \text { Polychlorinated Biphenyl-1254 } \\ \text { RCRA } & \text { Resource Conservation and Recovery Act, 1976 } \\ \text { RFI/RI } & \text { RCRA Facility Investigation/Remedial Investigation } \\ \text { ROD } & \text { Record of Decision } \\ \text { SCDHEC } & \text { South Carolina Department of Health and Environmental Control } \\ \text { SRS } & \text { Savannah River Site } \\ \text { WSRC } & \text { Westinghouse Savannah River Company }\end{array}$

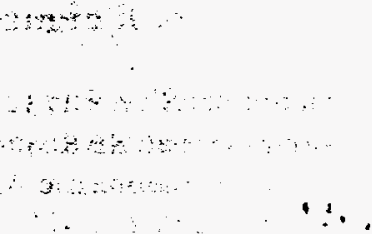




\section{EXECUTIVE SUMMARY}

This source unit Statement of Basis/Proposed Plan is being issued by the U. S. Department of Energy (DOE), which is the lead agency for remedial activities at the Savannah River Site (SRS), with concurrence by the U. S. Environmental Protection Agency (EPA) - Region IV and the South Carolina Department of Health and Environmental Control (SCDHEC).

The purpose of this source unit Statement of Basis/Proposed Plan is to describe the preferred alternative for addressing the F-Area Burning/Rubble Pits (231-F and 231-1F) and Rubble Pit (231-2F) (FBRP) source unit located at SRS, in southwestern Aiken County, South Carolina and to provide an opportunity for public input into the remedial action selection process. R.61-79.124 of the South Carolina Hazardous Waste Management Regulations (SCHWMR) and Section 1177(a) of the Comprehensive Environmental - Response, - Compensation, and Liability Act (CERCLA) requires advertisement of the draft RCRA permit modification and notice of proposed remedial actions (i.e., the Statement of Basis/Proposed Plan).

The FBRP are located about one half mile west of F-Area. Between 1951 and 1973, Pits 231-F and 231-1F were used to burn paper, plastics, wood, rubber, rags, cardboard, oil, degreasers, and spent solvents. Combustible materials were burned monthly. Pit $231-2 \mathrm{~F}$ was only used as a rubble pit. After burning was discontinued in 1973, Pits 231-F and 231-1F were also converted to rubble pits and used to dispose of concrete rubble, bricks, tile, asphalt, plastic, metal, wood products, and rubber. When the pits were filled to capacity in 1978, they were covered with compacted clay-rich native soil and vegetation was established:

The Resource Conservation and Recovery Act (RCRA) Facility Investigation/Remedial Investigation (RFI/RI) Report (WSRC, 1996a) determined that the majority of contaminants in the FBRP are located in the interval from four feet below surface to the bottom of Pits $231-\mathrm{F}$ and 231IF which is about 10 feet below the surface. Contaminant transport modeling demonstrates that these residual contaminants constitute little or no risk to groundwater.

Modeling in the Baseline Risk Assessment (BRA) (WSRC, 1996b) indicates that groundwater downgradient of the FBRP represents a total risk of $1 \times 10^{-4}$ and a hazard index of 3.0 for all pathways and contaminants. Contaminants responsible for this risk were also found in wells upgradient of the FBRP, possibly indicating an upgradient source for groundwater contamination. The source of this groundwater contamination has not been determined at this time.

During the RFI/RI, BRA, CMS/FS, and Statement of Basis/Proposed Plan review cycle, DOE, EPA, and SCDHEC decided that additional groundwater monitoring and assessment, including the sampling of several Cone Penetrometer Technology locations, will be conducted to delineate the source of the contamination (WSRC, 1996d). This source unit Statement of Basis/Proposed Plan will only concentrate on mitigating the risks from soil contamination in the FBRP. - Depending on the results of the groundwater assessment, three possible options have been recognized for addressing the groundwater contamination: 1) If no upgradient source is indicated, the contribution of the FBRP is confirmed and an independent Statement of Basis/Proposed Plan and ROD for the FBRP groundwater will be pursued; 2) If a previously unrecognized upgradient source is identified, a new groundwater operable unit will be created which will undergo Remedial Investigation/Feasibility Study assessment; 3 ) If an existing upgradient operable unit is determined to be the source of the contamination, the boundaries of the existing operable unit will be modified to include the groundwater contamination in the FBRP area.

Under an industrial land use scenario, ingestion of soil in the top two foot layer of Pits 231-F and 231IF poses a risk of $5 \times 10^{-6}$ from arsenic (28\% of the associated risk), heptachlorodibenzo-p-dioxin (24\%), and benzo(a)pyrene (18\%). This risk ( $5 \times$ $10^{-6}$ ) represents the probability of one excess cancer in a human population of two hundred thousand ( 1 in 200,000$)$ and is well within the 
EPA's target risk range of $1 \times 10^{-6}$ to $1 \times 10^{-4}(1$ in $1,000,000$ to 1 in 10,000 ).

Ingestion of soil in the 0-2 foot interval from $\mathrm{Pit}$ $231-2 \mathrm{~F}$ yields a risk of $4 \times 10^{-6}$ from polychlorinated biphenyl-1254 (PCB-1254) (93\% of the associated risk). The hazard index for ingestion of PCB-1254 contaminated soil in the 0-2 foot interval of Pit $231-2 \mathrm{~F}$ is 0.09 for future industrial workers, and 2.0 for possible future residents. The level of PCB-1254 contamination detected in the 0 to 2 foot interval $(2.87 \mathrm{mg} / \mathrm{kg})$ is below the Applicable, or Relevant and Appropriate Requirements (ARAR) of $10 \mathrm{mg} / \mathrm{kg}$ as established by the Toxic Substances Control Act and the EPA (1990) industrial to-be-considered guidance of 10 $\mathrm{mg} / \mathrm{kg}$. However, it exceeds the residential to-beconsidered guidance of $1 \mathrm{mg} / \mathrm{kg}$ (EPA, 1990).

Although these risks are within the target risk range, DOE in consultation with EPA and SCDHEC, determined that a corrective measures study/feasibility study was warranted because the hazard indices and risks associated with the chemicals of concern exceed threshold levels. The Corrective Measures Study/Feasibility study considered numerous possible soil treatment technologies for the soil contamination and developed detailed analyses for five alternatives.

\begin{tabular}{|c|c|}
\hline & Iternati \\
\hline 1 & No Action \\
\hline & Institutional Controls \\
\hline & Native Soil Cover (4') \\
\hline & Thermal Desorption/Incineration \\
\hline & Offsite Soil Disposal \\
\hline
\end{tabular}

The preferred alternative for remediating the FBRP is Alternative 2 Institutional Controls. The FBRP are located in an area which has been recommended for exclusive industrial use by the Citizens Advisory Board and the Savannah River Site Future Use Project Report (DOE, 1996).

Implementation of this alternative will require both short- and long-term actions, For the short-term, signs will be posted indicating that this area was used to manage hazardous materials. In addition, existing sRS access controls will be used to maintain the use of this site for industrial use only.
In the long-term, if the property is ever transferred to non-federal ownership, the U.S. Government will, in compliance with Section 120(h) of CERCLA, create a deed for the new- property owner. The deed shall include notification disclosing former waste management and disposal activities as well as remedial actions taken on the site. The deed notification shall, in perpetuity, notify any potential purchaser that the property has been used for the management and disposal of nonhazardous, inert construction debris, and that wastes containing hazardous substances, such as degteasers and solvents, were also managed and burned on the site.

The deed shall also include deed restrictions precluding residential use of the property. However, the need for these deed restrictions may be reevaluated at the time of transfer in the event that contamination no longer poses an unacceptable risk under residential use.

In addition, if the site is ever transferred to nonfederal ownership, a survey plat of the area will be prepared, certified by a professional land surveyor, and recorded with the appropriate county recording agency.

Throughout the period of Federal ownership, as well as for any future ownership, under Institutional Controls (Alternative 2), there will be no risk greater than $5 \times 10^{-6}$ or hazard index greater than 0.1 to future industrial workers. Furthermore, there will be no appreciable risk to the environment.

Community involvement in the remedial alternative selection process for the FBRP is -. strongly encouraged. Section II includes SRS contact information to request a public meeting, to obtain additional information about this Statement of Basis/Proposed Plan, or to submit comments.

All submitted comments will be reviewed and considered prior to final selection of an alternative. A Responsiveness Summary will be prepared to address significant issues raised during the public comment period, and it will be made available with the final RCRA permit and Record of Decision (ROD). The final RCRA permit and the ROD document the final decision for the unit. in. 


\section{SECTION I INTRODUCTION AND BACKGROUND}

\section{Introduction}

This source unit Statement of Basis/Proposed Plan is issued by DOE, which is the lead agency for SRS remedial activities, with concurrence by EPA and SCDHEC. The purpose of the source unit Statement of Basis/Proposed Plan is to describe the preferred alternative for addressing the FBRP source unit located in southwestern Aiken County, South Carolina and to provide for public involvement in the decision-making process.

SRS manages certain waste materials which are regulated under RCRA, a comprehensive law, requiring responsible management of hazardous waste. RCRA 3004(u) requires that releases from solid waste management units be investigated and remediated as necessary. The FBRP are a solid waste management unit regulated under RCRA 3004(u).

On December 21, 1989, SRS was included on the National Priorities List. This inclusion created a need to integrate the established RCRA Facility Investigation Program with CERCLA requirements to provide for a focused environmental program. In accordance with Section 120 of CERCLA, DOE has negotiated a Federal Facility Agreement with EPA and SCDHEC to coordinate remedial activities at SRS into one comprehensive strategy which fulfills these dual regulatory requirements. The Federal Facility Agreement lists the FBRP (231-F, 231-1F, and 231-2F) as a RCRA/CERCLA unit, thus requiring further evaluation under an investigation/assessment process that integrates and combines the RCRA Facility Investigation process with the CERCLA Remedial Investigation to determine the actual or potential impact to human health and the environment.

Both RCRA and CERCLA require that the public be given the opportunity to review and comment on the draft permit modification and proposed remedial alternative. Public participation requirements are listed in SCHWMR R.61-79.124 and Sections 113 and 117 of CERCLA. These requirements include establishment of an
Administrative Record File that documents the selection of remedial alternatives and allows for review and comment by the public regarding those alternatives (see Section In). The-Administrative Record File must be established "at or near the facility at issue." The SRS Public Involvement Plan (DOE, 1994) is designed to facilitate public involvement in the decision-making process for permitting, closure, and the selection of remedial alternatives. SCHWMR R.61-79.124 and Section 117(a) of CERCLA require advertisement of the draft permit modification and proposed remedial action and provide the public an opportunity to participate in the selection of a remedial action.

This source unit Statement of Basis/Proposed Plan is a summary of the Administrative Record File leading to selection of the preferred alternative. The source unit Statement of Basis/Proposed Plan presents the preferred alternative and the rationale for selecting that alternative. Community involvement in consideration of this evaluation of alternatives for the FBRP is strongly encouraged. SCHWMR R.61-79.124 requires that a brief description and response to all significant comments be made available to the public as a part of the RCRA Administrative Record. All submitted comments will be reviewed and contsidered. Following the public comment period, a Responsiveness Summary will be prepared to address significant issues raised during the comment period. The Responsiveness Summary will be made available with the final RCRA permit and the ROD. In order to gain a better understanding of RCRA and CERCLA activities as they pertain to the FBRP, the public is encouraged to review the Administrative Record File for this unit. Refer to Section II of this document for information regarding availability of and access to the Administrative Record.

The final selection of the remedial alternative under RCRA will be in the form of a final permit modification decision which is made by SCDHEC. The remedial alternative, that will satisfy the FFA requirements, will be selected by DOE, in consultation with EPA and SCDHEC, only, after the public comment period has ended and all comments submitted have been reviewed and considered. It is important to note that the final action may be 
different from the preferred alternative discussed in this plan, depending on new information or public comments. The altermative chosen will be protective of human health and the environment and will comply with all Federal and South Carolina State environmental laws.

\section{Background}

SRS occupies approximately 310 square miles of land adjacent to the Savannah River, principally in Aiken and Barnwell Counties of South Carolina. SRS is a secured U. S. Government facility with no permanent residents. SRS is located approximately 25 miles southeast of Augusta, Georgia and 20 miles south of Aiken, South Carolina. Figure 1 shows the location of the FBRP in relation to other facilities at SRS and Figure 2 shows the layout of the FBRP with sample locations and monitoring wells.

\section{SECTION I COMMUNTTY INVOLYEMENT}

This Statement of Basis/Proposed Plan summarizes information from the documents listed in the REFERENCES Section of this Statement of Basis/Proposed Plan. These unabridged documents are part of the FFA Administrative Record File, which is available for review by the public at the following locations:

U.S. Department of Energy

Public Reading Room

Gregg-Graniteville Library.

University of South Carolina-Aiken

171 University Parkway

Aiken, South Carolina 29801

(803) 641-3465
Thomas Cooper Library

Government Documents Department

University of South Carolina

Columbia, South Carolina 29208

(803) $777-4866$

Similar information is available through the repositories listed below:

Reese Library, Augusta State University 2500 Walton Way

Augusta, Georgia 30910

(706) $737-1744$

Asa H. Gordon Library, Savannah State University Thompkins Road

Savannah, Georgia 31404

(912) 356-2183

The RCRA Administrative Record . File for SCDHEC is available for, review by the public at the following locations:

The South Carolina Department of Health and Environmental Control

Bureau of Solid and Hazardous of Waste $^{2}$ Management 0 stets

8901 Farrow Road

Columbia, South Carolina 29203

(803) $896-4000$

Lower Savannah District

Environmental Quality Control Office

215 Beaufort St, N.E.

Aiken, South Carolina 29802

(803) 641-7670

The public will be notified of a public comment period through mailing of the SRS Environmental Bulletin, a newsletter sent to approximately 3500 citizens in South Carolina and Georgia and through the Aiken Standard the Allendale Citizen Leader, the Barnwell People Sentinel, The State, and the Augusta Chronicle newspapers: The public comment period will also be announced on local radio stations.

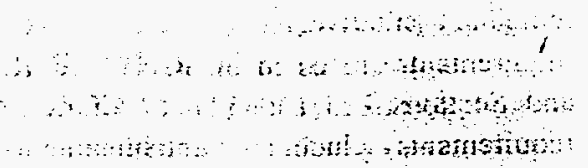


Figure 1 Location of the F-Area Burning/Rubble Pits (231-F and 231-1F) and Rubble Pit (2312F) in Relation to Major Savannah River Site Facilities

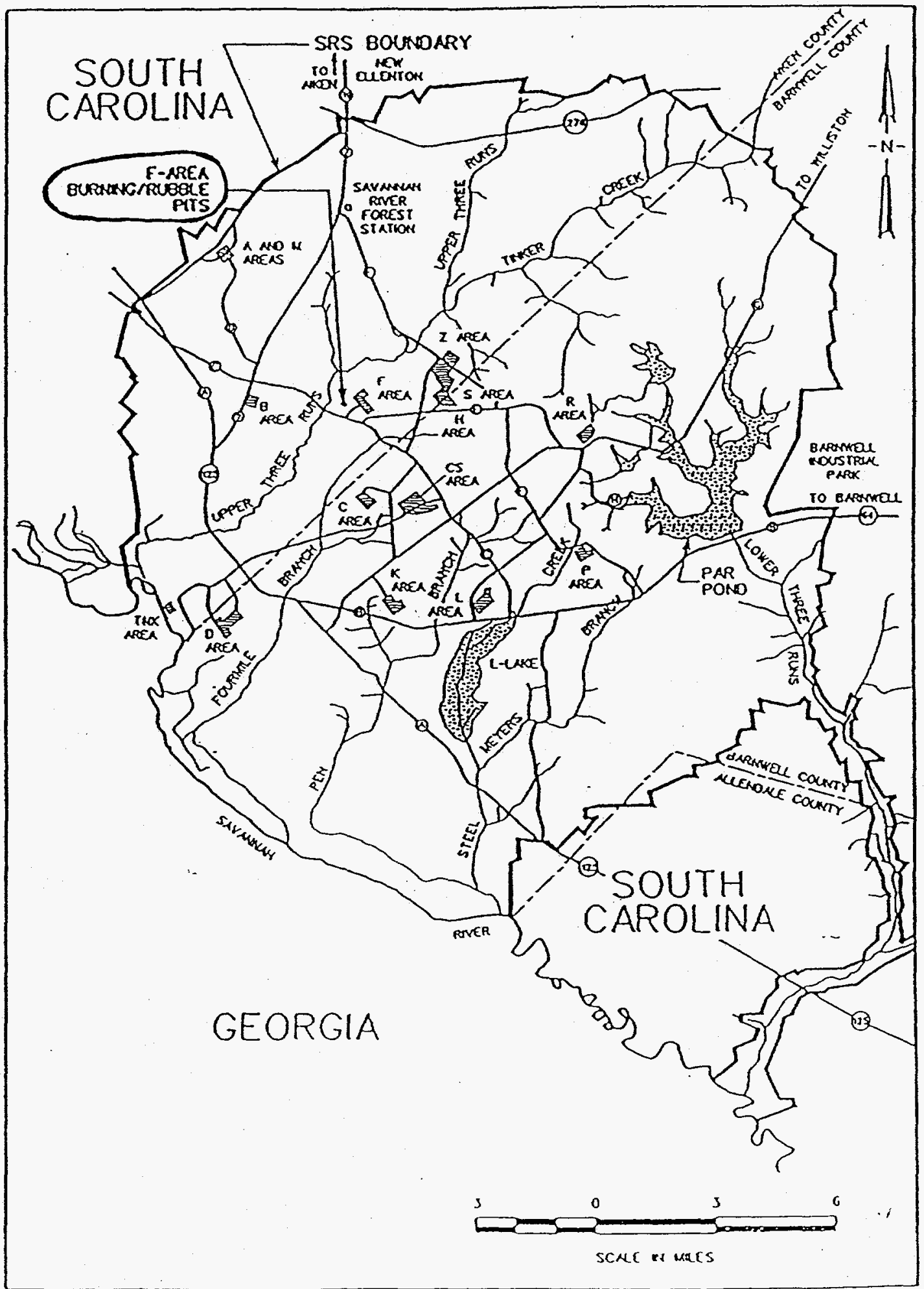




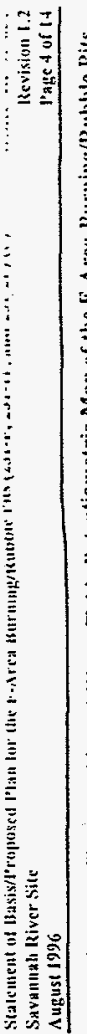
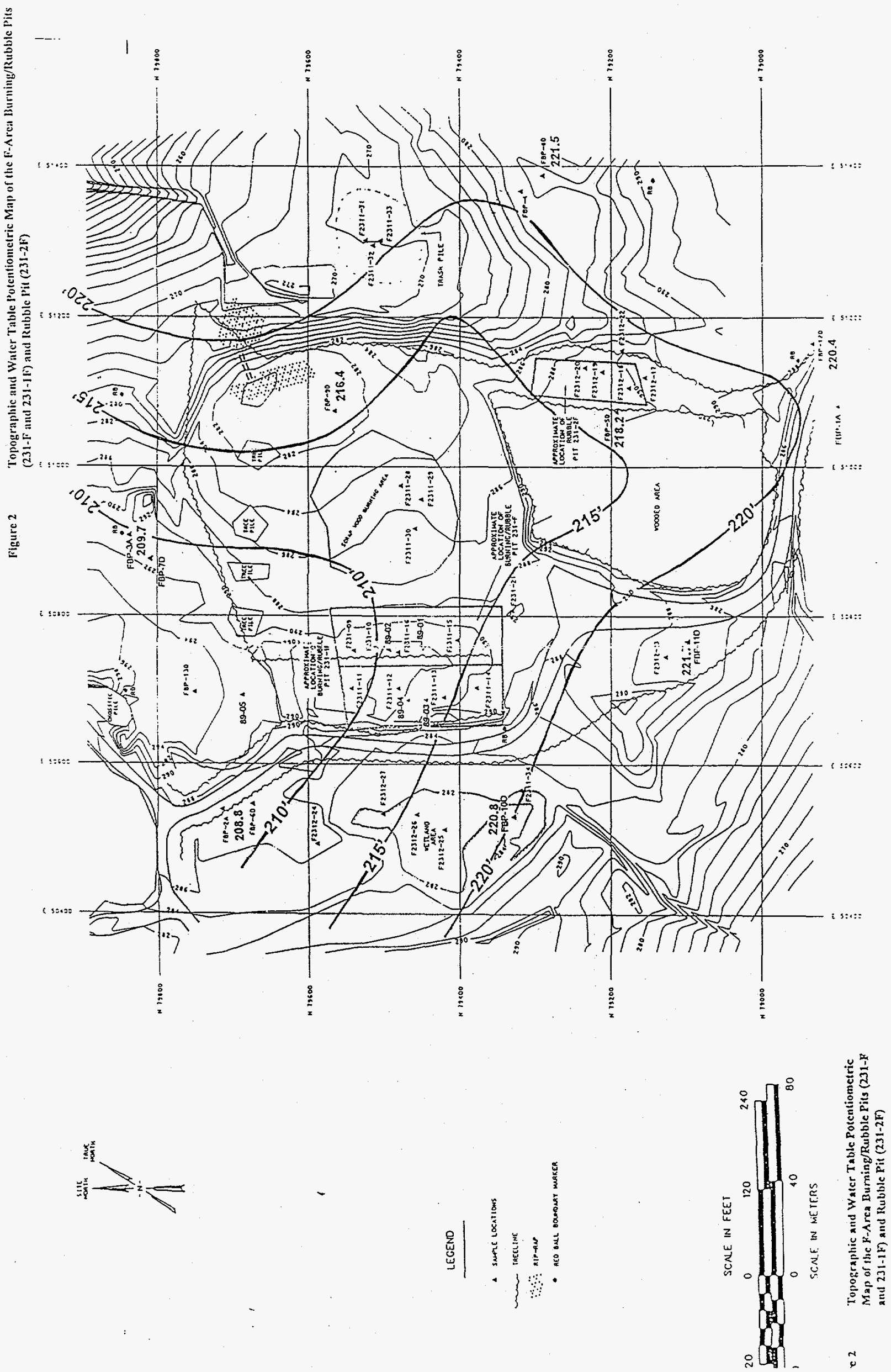
DOE will provide an opportunity for a public meeting during the public comment period if significant interest is expressed. The public will be notified of the date, time, and location. At the meeting, the proposed action will be discussed and questions about the action will be answered.

To request a public meeting during the public comment period, to obtain more information concerning this Statement of Basis/Proposed Plan, or to submit written comments contact one of the following:

\section{A. Flora}

Public Involvement

Westinghouse Savannah River Company

Savannah River Site

Building 730-2B

Aiken, South Carolina 29808

(803) $952-6852$

The South Carolina Department of Health and Environmental Control

Attn: G. Randall Thompson, P. E., Director

Division of Hazardous and Infectious Waste

Bureau of Solid and Hazardous Waste Management

2600 Bull Street

Columbia, South Carolina 29201

(803) $896-4000$

Following the public comment period, a ROD will be signed and a final decision for the RCRA permit will be issued. The ROD and RCRA permit will detail the remedial alternative chosen for the site and will include responses to oral and written comments received during the public comment period in the Responsiveness Summary.

\section{SECTION MI SCOPE AND ROLE OF OPERABLE UNIT (RESPONSE ACTION) WITHIN THE SITE STRATEGY}

The FBRP comprise a potential source control and groundwater operable unit, located within the Upper Three Runs Watershed. Source control and groundwater operable units within this watershed will be evaluated to determine impacts, if any, to associated streams and wetlands. SRS will manage all source control units to prevent impact to the Upper Three Runs Watershed. The proposed action for the FBRP source unit is intended as a final action. Upon disposition of att source control and groundwater operable units within this watershed, a final, comprehensive ROD for the watershed will be pursued.

Groundwater contamination has been documented during the FBRP groundwater monitoring program in both upgradient and downgradient wells. This contamination may be due to migration from undetermined, upgradient sources and will not be addressed in this remedial action selection process. Additional assessment of the groundwater contamination will be conducted under the proposed groundwater assessment addendum to the Work Plan (WSRC, 1996d). The results of this groundwater assessment program to be completed within six months will determine if the groundwater contamination is addressed under the FBRP groundwater operable unit, a new upgradient groundwater operable unit, or an existing upgradient groundwater operable unit:

The schedule for the additional groundwater assessment is contained within the Work Plan Addendum (WSRC 1996d) The schedule includes performing cone penetrometer technology sampling, data validation, and report preparation and submittal. These activities should be completed by early fiscal year 1997 .

$$
\text { Anetro }
$$

SECTION IV MEDIA SPECIFIC OPERABLE UNIT - THE FBRP TBR an:

Section IV.A Unit Description, History, and Média Assessment

Unit Description and Location

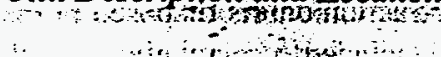

The FBRP comprise a RCRA/CERCLA waste unit located within the $S R S$, approximately 3000 feet west of F-Area and 1100 feet north of SRS Road C. Upper Three Runs is 10 cated approximately 2,300 feet northwest of the pits. The local topography of the area is flat uplatid and the pits are at an elevation of 290 teenabove mean sea level and 170 feet above Upper Three Runs. The water table is 
70 to 100 feet below ground surface in the area of the FBRP. Surface drainage is to the northwest toward an ephemeral tributary of Upper Three Runs about 7.5 miles upstream of its confluence with the Savannah River.

The two contiguous burning/rubble pits, which cover a total area of 1.05 acre, are designated as 231-F and 231-1F; a twenty foot wide berm of undisturbed soil separates these two pits. The rubble pit (231-2F) covers about 0.13 acre. Approximate dimensions of the pits are:
o 231-F:
275 feet $\times 62$ feet $\times 10$ feet
o 231-1F: 325 feet $\times 89$ feet $\times 10$ feet
- 231-2F: 165 feet $\times 33$ feet $\times 4-9$ feet.

The pits have been backfilled with soil; the pit cover is mounded above the surrounding terrain, which is essentially level, to enhance drainage. Vegetation has been established on the pits to reduce erosion.

\section{History of the Unit}

Between 1951 and 1973, SRS used Pits 231-F and $231-1 F$ to bum a variety of wastes which were considered non-hazardous at that time. Some of these waste materials (degreasers and solvents) are now considered to be hazardous based on ingestion or possible dermal contact. Waste was usually burned on a monthly basis. The chemical composition and volumes of the disposed waste are unknown, but waste materials burned included paper, plastics, wood, rubber, rags, cardboard, oil, degreasers, and spent organic solvents. No known or suspected radioactive materials were allowed in the burning pits. These radioactive wastes were managed in the Radioactive Waste Burial Ground about 1.5 miles east. Pit $231-2 \mathrm{~F}$ was used exclusively as a rubble pit. Large volumes of uncontaminated construction debris disposed in the pits may have included relatively small, nonliomogeneously distributed amounts of low level contamination by cesium-137, strontium-90, and iodine-129 Traces of these radionuclides may also have entered the burning/rubble pits as fallout. Uranium-238 radium-226, and potassium-40 are all naturally occurring radionuclides radium is always associated with uranium Granitic rocks, such as those that make up much of the southern Appalachian source area for the coastal plain sediments are about twice as rich in uranium and potassium as the average crustal abundance.

Burning of waste in the SRS pits was discontinued by October 1973. A layer of soil was then placed over the residue in the pits and they were subsequently used as rubble pits. Materials allowed in the rubble pits included concrete, bricks, tile, asphalt, plastic, metal, empty drums, wood products, and rubber. When the pits were filled to capacity in 1978, a layer of clayey soil was placed over the contents and the surface was compacted and mounded. Vegetation has been established to reduce erosion.

\section{Media Assessment}

The Data Summary Report (WSRC, 1994), RFI/RI Report (WSRC, 1996a), BRA (WSRC, 1996b), and Corrective Measures Study/Feasibility Study (WSRC, 1996c) contain detailed analytical data for all of the environmental media samples taken in the characterization of the FBRP These documents are available in the Administrative Record (See Section II).

SOILs ${ }^{4} \therefore$.

Analytical data indicate that little or no significant contamination of the soil outside of the FBRP has occurred. During the preparation of the RFI/RI Report, it was noted that chemicals of potential concer (including arsenic, benzo(a)pyrene, cadmium, cestum-137, chromium, heptachlorodibenzo-p-dioxin, lead, manganese, PCB-1254, and radium) were confined to the debris interval of the soil within the pits. This distribution and the contaminant trarisport modeling results indicate limited mobility of these contaminants in the soil. Despite being a groundwater risk driver, carbon tetrachlonde was not detected in the soil of the FBRP source unit The approximate pit boundaries and sample locations are shown on Figure 2.

Arsenic was found in most of the samples from the debris interval in Pits $231-\mathrm{F}$ and $231-1 \mathrm{~F}$, but was only found in one sample in Pit $231-2 \mathrm{~F}$ The highest value reported was $15.2 \mathrm{mg} / \mathrm{kg}$ (parts per 
million) in the 2-4 foot interval of boring 16 in Pit 231-F. Cadmium was only found in nine samples from Pits 213-F and 231-1F, with a maximum value of $22.2 \mathrm{mg} / \mathrm{kg}$ in the $6-8$ foot sample from boring 13 in Pit 231-1F. This sample also yielded the highest reported values for chromium $(16,000$ $\mathrm{mg} / \mathrm{kg}$ ), copper (917 $\mathrm{mg} / \mathrm{kg}$ ), manganese (1030 $\mathrm{mg} / \mathrm{kg}$ ), and nickel (7140 $\mathrm{mg} / \mathrm{kg}$ ), suggesting a concentration of metals from a single source.

The maximum value for benzo(a)pyrene was 2.37 $\mathrm{mg} / \mathrm{kg}$, found in the $4-6$ foot interval of boring 14 in Pit 231-1F. Benzo(a)pyrene was only identified in a single sample from $P i t$ 231-2F. Heptachlorodibenzo-p-dioxin was found in two samples in Pit 231-2F and 16 samples in Pits 231-F and 231-1F. The maximum value, $0.009 \mathrm{mg} / \mathrm{kg}$, was reported from the 6-8 foot interval in boring 13, Pit 231-1F. PCB-1254 was found in four samples in Pit $231-2 F$, including the highest value, $9.14 \mathrm{mg} / \mathrm{kg}$, an estimated value, in the $6-8$ foot interval in boring 17 . This value is less than the industrial cleanup goal of $10 \mathrm{mg} / \mathrm{kg}$. The 18 detects in Pits 231-F and 231-1F were all less than the residential cleanup goal of $1 \mathrm{mg} / \mathrm{kg}$ PCB-1254.

Cesium-137 was found in 11 samples in Pit 231-2F and 27 samples from Pits $231-\mathrm{F}$ and $231-1 \mathrm{~F}$. The highest value was $32.4 \mathrm{pCi} / \mathrm{g}$ in the $8-10$ foot sample from boring $12, \mathrm{Pit} 231-1 \mathrm{~F}$. The maximum value for total alpha emitting radium was $4 \mathrm{pCi} / \mathrm{g}$ in the $6-8$ foot interval in boring 13 , Pit 231-1F.

\section{Section IV.B Operable Unit Risks}

\section{Human Health Risk Assessment}

As part of the investigation/assessment process for the FBRP, a BRA was performed using data generated during the assessment phase. Detailed information regarding the development of chemicals of potential concern, the fate and transport of contaminants, and the risk assessment can be found in the RFIRI and BRA reports. The process of designating the chemicals of concern was based on consideration of background concentrations, frequency of detection, the relative toxic potential of the chemicals, and human nutrient requirements. Chemicals of potential concern are the constituents that are potentially site-related and are reported at a sufficient data quality level for use in the risk assessment.

An exposure assessment was performed to provide an indication of the potential exposures which could occur based on the chemical concentrations detected during sampling activities. The only current exposure scenario identified for the FBRP was for on-site visitors. Conservative future exposure scenarios identified for the FBRP included future industrial workers and future resident adults and children. The reasonable maximum exposure concentration value was used as the exposure point concentration.

Carcinogenic risks are estimated as the incremental probability of an individual developing cancer over a lifetime as a result of pathway-specific exposure to cancer-causing contaminants. The risk to an individual resulting from exposure to nonradioactive chemical carcinogens is expressed as the increased probability of cancer occurring over the course of a 70 year lifetime. Cancer risks are related to the target risk range of one excess human cancer in a population of ten thousand $\left(1 \times 10^{-4}\right)$ to one in one million $\left(1 \times 10^{-6}\right)$ for incremental cancer risk at National Prionities List sites.

$$
\text { ( i }
$$

Non-carcinogenic effects are also evaluated to identify a level at which there may be concern for potential non-carcinogenic health effects. The hazard quotient, which is the ratio of the exposure dose to the reference dose, is calculated for each contaminant Hazard quotients are summed for each exposiure pathway to determine the specific hazard index for each exposure scenario. If the hazard index exceeds unity (1.0), there is concern that adverse health effects might occur.

\section{Current Land Use - Noncarcinogenic Hazards}

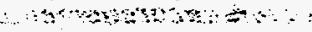

The BRA shows that potential adverse noncarcinogenic health effects are not likely to occur, because none of the hazard indices exceeds a value of one. 
Current Land Use - Carcinogenic Risks

Under the current land use scenario, human health risks were characterized for the current on-unit visitor. The highest estimated nonradiological cancer risk was $2 \times 10^{-8}$ for soil ingestion from all pits. Media evaluated include soil inside the FBRP source unit, soil outside the FBRP source unit, associated airborne soil particulates, and surface water and sediment in an adjacent seasonal wetland.

The highest estimated radiological risk for each pathway was: $3 \times 10^{-7}$. for direct radiation in all the pits; $2 \times 10^{-10}$ for ingestion of soil in the $231-2 \mathrm{~F}$ pit; and $3 \times 10^{-12}$ for inhalation of particulates from soil inside the FBRP.

\section{Future Industrial Land Use - Noncarcinogenic Hazards}

The hazard indices were less than one for all constituents by all exposure pathways.

\section{Future Industrial Land Use-Carcinogenic Risks}

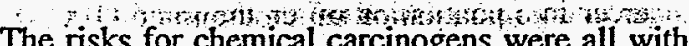
The risks for chemical carcinogens were all within or below the target risk range., The maximum risk from soil ingestion was $5 \times 10^{-6}$ driven by arsenic, heptachlorodibenzo-p-dioxin, and benzo(a)pyrene in Pits $231-\mathrm{F}$ and $231-1 \mathrm{~F}$ and $4 \times 10^{-6}$ driven by $\mathrm{PCB}-1254$ in Pit $231-2 \mathrm{~F}$.

Carcinogenic risk for radiological exposur

Carcinogenic nisk for radiological exposure was within the target risk range for all pathways. The highest risk under this pathway was $3 \times 10^{6}$ for exposure to soil fom the $231 \mathrm{~F}$ and $231-1 \mathrm{~F}$ pits. This risk was driven by cesium-137 and potassium40. Potassium 40 is a naturally occurring radionuclide.

Future Residential Land Use - Noncarcinogenic Hazards

The

The hazard indices for noncarcinogenic hazards under a future resident scenario were less than one for all pathways except ingestion of soil from Pit 231-2F and ingestion of groundwater. The hazard index for ingestion of soil was 2.0, predominantly driven by PCB-1254 in Pit 231-2F.

\section{Future Residential Land Use - Carcinogenic} Risks

The nonradiological ingestion and dermal exposure pathways for the future on-unit resident had estimated carcinogenic risks within the target risk range. The highest risks were $2 \times 10^{-5}$ for the soil ingestion pathway in Pits 231-F and 231-1F, driven by arsenic, benzo(a)pyrene, and heptachlorodibenzo-p-dioxin; $2 \times 10^{-5}$ for the soil ingestion pathway in $\mathrm{Pit} 231-2 \mathrm{~F}$, driven by $\mathrm{PCB}-$ 1254.

Carcinogenic risk for radiological exposure was within or below the target risk range for all pathways. - The highest risk under the direct radiation pathway was $1 \times 10^{-5}$ for exposure to soil from the $231-\mathrm{F}$ and $231-1 \mathrm{~F}$ pits. This risk was driven by cesium- 137 and potassium-40.

\section{Ecological Risk Assessment}

Based on characterization of the environmental setting and identification of potential receptor organisms, a conceptual site model was developed to determine the complete exposure pathways through which receptors could be exposed to chemicals of potential concern.

$$
\therefore
$$

Interpretation of the ecological significance of the unit-related contamination at the FBRP source unit concluded that there was no likelihood of unitrelated chemicals causing significant impacts to the community of species in the vicinity of the unit.

\section{Site-Specific Considerations}

$$
\text { \% }
$$

Site-specific considerations, based on the conclusions of the BRA and RFIRI, which suggest limited or no potential for significant risk include:

1) The FBRP contain a large volume of buried nonhazardous waste material and cover soil.

2) The levels of contamination recognized during Phase II characterization are generally, very low; there is a preponderance of "non-detects". The contaminants are very stable chemically and exhibit limited mobility in the soil. 
3) The groundwater monitoring program indicates that there has not been significant impact from the waste materials in the pits.

4) The FBRP are in a remote area which has been recommended as an industrial zone by the Citizens Advisory Board and the Savannah River Site Future Use. Project Report (DOE, 1996), precluding future residential use.

\section{Remedial Action Objectives}

Remedial action objectives specify unit-specific contaminants, media of concern, potential exposure pathways, and remediation goals. The remedial action objectives are based on the nature and extent of contamination, threatened resources; and the potential for hüman and environmental exposure. Initially, preliminary remediation goals are developed based upon ARARs, or other information from the RFI/RI Report and the BRA. These goals should be modified, as necessary, as more information concerning the unit and potential remedial technologies becomes available.: Final remediation goals will be determined when the remedy is selected and shall establish acceptable exposure levels that are protective of human health and the environment.

Chemicals of potential concem are site- and mediaspecific,-" man-made and naturally occurring inorganic and organic chemicals, pesticides, and radionuclides detected at a unit under investigation. Chemicals of concern are isolated from the list of chemicals of potential : concern by icalculating carcinogenic risks and noncarcinogenic hazard indices.: A chemical of concern contributes significantly to a pathway having a carcinogenic risk greater than $1 \times 10^{-4}$ and a hazard index greater than 1:0. Risk levels at or above the upper-bound of the target risk range $1 \times 10^{-4}$ are considered significant and these sites are expected to undergo remediation. Risk levels between $1 \times 10^{-6}$ and $1 \times$ $10^{-4}$ require consideration for remediation.

ARARs are those cleanup standards, standards of control, and other substaritive requirements, criteria, or limitations promulgated under federal, state, or local environmental law that specifically address a hazardous st substance; pollutant, contaminant, remedial action, location, or other circumstance at a CERCLA site. Three types of ARARs; action-, chemical-, and location-specific; have been developed to simplify identification and compliance with environmental requirements. Action-specific requirements set controls on the design, performance and other aspects of implementation of specific remedial activities. Chemical-specific requirements are media-specific, health-based concentration limits developed for site-specific levels of contaminants in specific media. Location-specific ARARs must consider Federal, State, and local requirements that, reflect the physiographical and environmental characteristics of the unit or the immediate area.

There were no action-specific or location-specific ARARs relevant to establishing remedial action objectives for the FBRP source unit. The only chemical-specific ARAR identified was for PCBs. The Toxic Substances Control Act establishes an ARAR of $10 \mathrm{mg} / \mathrm{kg}$ of PCBs in soil. The maximum level of PCBs found in the 0 to 2 foot interval in any of the pits was $2.87 \mathrm{mg} / \mathrm{kg}$ in $231-2 \mathrm{~F}$. This value is below the ARAR: W

None of the risks associated with the soil in the FBRP source unit has been found to be greater than $1 \times 10^{-4}$. The only hazard index that exceeded 1.0 was for PCB-1254 from the 0-2 foot soil interval in Pit 231-2F for future residents. The hazard index for this exposure scenario was 2.0. The only guidance that was exceeded for soil concentrations was for PCB-1254 which had a maximum value of $2: 87 \mathrm{mg} / \mathrm{kg}$ in the 0 to 2 foot interval The to-beconsidered guidance for $P C B$ is recommended soil action levels of $1.0 \mathrm{mg} / \mathrm{kg}$ for residential use and $10-25 \mathrm{mg} / \mathrm{kg}$ for industrial use (EPA, 1990). The

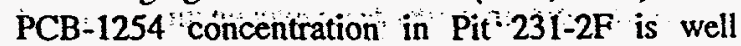
below the range for industrial land use.

\section{SECTION V ALTERNATIVE ANALYSIS}

\section{Section V.A Summary of Alternatives}

The RFI/RI and BRA indicate that the FBRP source unit poses no significant risk to the environment and minimal risk to human health when teasonable exposure scenarios are assumed. 
Although the risks are generally within the target risk range, this Corrective Measures Study/Feasibility Study was conducted to consider possible actions which could reduce the risks to $1 \mathrm{x}$ $10^{-6}$ or less.

The Corrective Measures Study/Feasibility Study included detailed analyses for five alternatives which are described below.

\section{Alternative 1. No Action}

Under this altemative, no action would be taken at the FBRP. EPA policy and regulations require consideration of a no action alternative to serve as a basis against which other alternatives can be compared. Because no further action would be taken and the FBRP would remain in their present condition, there are no costs associated with this alternative and there would be no reduction or mitigation of risk.

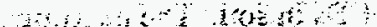 \\ Alternative 2 Institutional Control}

Under this alternative, institutional controls would be implemented at the FBRP. Implementation of this alternative will require both short-and longterm actions for the short-term, signs isvill be posted indicating that this area was used to manage hazardous materials. In addition, existing SRS access controls will be used to maintain the use of this site for industrial use only.

In the long-term, if the property is ever transferted to non-federal ownership, the U.S Government will, in compliance with, Section $120(\mathrm{~h})$ of CERCLA create a deed for the new property owner. The deed shall include notification disclosing former waste management and disposal activities as well as remedial actions taken on the site. The deed notification shall, in perpetuity, notify any potential purchaser that the property has been used for the management and disposal of nonhazardous, ineer construction debris, and that wastes containing hazardous substances, such as degreasers and solvents, were also managed and burned on the site.

$$
1 \text { s. }
$$

The deed shall also include deed restrictions precluding residential use of the property.
However, the need for these deed restrictions may be reevaluated at the time of transfer in the event that contamination no longer poses an unacceptable risk under residential use.

In addition, if the site is ever transferred to nonfederal ownership, a survey plat of the area will be prepared, certified by a professional land surveyor, and recorded with the appropriate county recording agency.

There are no construction costs associated with this alternative. The cost for surveying the land, installing signs, and filing with the Aiken County Records is estimated to be $\$ 2,000$. If five year reviews of remedy are required, the estimated present value for these reviews over the next 30 years is $\$ 8,000$. The total present value cost for Alternative 2 would be $\$ 10,000$.

The remaining risk via soil ingestion to future onsite workers would be $5 \times 10^{-6}$ and the hazard index would be 0.02 for Pits 231-F and -1F.The risk and hazard index from Pit $231-2 F$ would be $4 \times 10^{-6}$ and 0.09 respectively: $\quad: \quad$ a

Fin and

Alternative 3. Native Soil Cover (4')

Under this alternative, a four foot thick cover of native soil would be installed over the present surface of each of the pits to reduce the likelihood that future excavation for construction of a typical basement would expose waste or contaminated soil. If the property is ever transferred to private ownership, in compliance with CERCLA 120(h), the U.S. Government will create a deed with notifications and restrictions similar to those identified in Alternative 2. A deed restriction prohibiting excavation below four feet would also be filed in Aiken County Records. : The deed restrictions on excavation below four feet would be necessary to prevent potential exposure of future workers or residents to buried waste which may contain . low, : concentrations of hazardous constituents.

The cost for developing a CERCLA Remedial Design/Remedial Action Work Plan,would be $\$ 50,000$. The construction costs associated with this alternative are estimated at $\$ 347,000$ for the 
installation of a four foot thick native soil cover. The cost for surveying the land, installing signs, and filing with the Aiken County Records is estimated to be $\$ 2,000$. Present value costs of maintenance over 30 years is $\$ 8000$. If five year reviews of remedy are required, the estimated present value for these reviews over the next 30 years is $\$ 8,000$. Total present value costs for this alternative are estimated at $\$ 415,000$.

Remaining risks from the pits would be insignificant. The hazard indices from all pits would be less than 1:0.

\section{Alternative 4. Thermal Desorption/Incineration}

Under this alternative, the upper four feet of contaminated soil and waste in the pits would be excavated for treatment to eliminate the PCB-1254 and other organic contaminants by thermal desorption/incineration. The soil would be fed through a high temperature rotary kiln to extract the volatile organic contaminants from the soil." The extracted gases would then be destroyed in the incinerator- The treated soil would be returned to the site and vegetation would be established to prevent erosion. If the property is ever transferred to private ownership, in compliance with CERCLA $120(\mathrm{~h})$, the U.S. Government will create a deed with notifications and restrictions similar to those identified in Alternative 2. Deed restrictions on excavation below four feet would be necessary to prevent potential exposure of future workers or residents to buried waste which may contain low levels of hazardous constituents.

A National Emission Standards for Hazardous Air Pollutants permit would be required because of the potential for atmospheric releases during remediation; the cost of obtaining this permit would be $\$ 150,000$. The estimated cost for developing a CERCLA Remedial Design/Remedial Action Work Plan would be $\$ 150,000$. The cost for excavation and backfilling would be $\$ 412,000$. The cost for thermal desorption/incineration is $\$ 6,166,000$. The deed notifications and restrictions would cost $\$ 2,000$. The total cost for this alternative would be $\$ 6,880,000$.
This alternative is protective of human health and would permanently reduce risk to less than $1 \times 10^{-6}$ for ingestion of soil in Pit 231-2F. The remaining risk to future residents would be $6 \times 10^{-6}$ (from arsenic) for nonradiological exposure and $1 \times 10^{-5}$ for radiological exposure for direct radiation in Pits $231-\mathrm{F}$ and $231-1 \mathrm{~F}$ and $8 \times 10^{-6}$ for pit $231-2 \mathrm{~F}$. The risk for ingestion of fruit is $3 \times 10^{-6}$ for BRPs $231-\mathrm{F}$ and $-1 \mathrm{~F}$ and $2 \times 10^{-6}$ for RP 231-2F. The risks from ingestion of leafy vegetables is $6 \times 10^{-6}$ for the BRPs and $5 \times 10^{-6}$ for the RP. The risk from ingestion of tuberous vegetables is $4 \times 10^{-6}$ for the BRPs and $3 \times 10^{-6}$ for the RP.

\section{Alternative 5. Offsite Soil Disposal}

Under this alternative, the upper four feet of soil in the pits would be excavated and transported to a licensed offsite disposal facility. The excavation would be filled to grade with clean native soil and cover vegetation would be established. If the property is ever transferred to private ownership, in compliance with CERCLA 120(h), the U.S. Government will create a deed with notifications and restrictions similar to those identified in Alternative 2.: Deed restrictions on excavation below four feet would also be necessary to prevent potential exposure of future workers or residents to buried waste which may contain low levels of hazardous constituents.

The cost for developing a CERCLA Remedial Design/Remedial Action Work Plan would be $\$ 150,000$. The cost for excavation and backfilling would be $\$ 411,000$. The cost for transportation is estimated to be $\$ 761,000$. The cost for disposal is $\$ 3,350,000$. The deed notifications and restrictions would cost $\$ 2,000$. The total cost for this alternative would be $\$ 4,674,000$.

This alternative is protective of human health and would permanently reduce risk to less than $1 \times 10^{-6}$ for soil related risks in all of the pits.

\section{Section V:B Preferred Alternative}

The preferred action at the FBRP is institutional controls (Alternative 2). 
Implementation of this alternative will require both short- and long-term actions. For the short-term, signs will be posted indicating that this area was used to manage hazardous materials. In addition, existing SRS access controls will be used to maintain the use of this site for industrial use only.

In the long-term, if the property is ever transferred to non-federal ownership, the U.S. Government will, in compliance with Section 120(h) of CERCLA, create a deed for the new property owner. The deed shall include notification disclosing former waste management and disposal activities as well as remedial actions taken on the site. The deed notification shall, in perpetuity, notify any potential purchaser that the property has been used for the management and disposal of nonhazardous, inert construction debris, and that wastes containing hazardous substances, such as degreasers and solvents, were also managed and burned on the site

The deed shall also include deed restrictions precluding residential use of the property. However, the need for these deed restrictions may be reevaluated at the time of transfer in the event that contamination no longer poses an unacceptable nisk under residential use.

In addition, if the site is ever transferred to nonfederal ownership, a survey plat of the area will be prepared, certified by a professional land surveyor, and recorded with the appropriate county recording

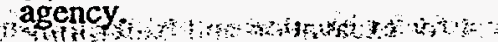

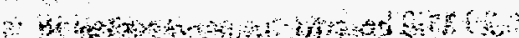

The Institutional Controls Alternative is intended to be the final action for the FBRP source unit The solution is intended to be permanent and effective in both the long and short terms. Alternative 2 is considered to be the least cost option that is still protective of human health and the environment. Alternatives 3,4 , and 5 offer only an incremental reduction in risk and hazard for a substantial increase in cost (up to 688 times).

This proposal is consistent with EPA guidance and the National Contingency Plan for sites that have relatively large volumes of waste with low levels of contamination and is an effective use of risk management principles.
Further assessment of the groundwater contamination will be conducted under the groundwater assessment program addendum to the Work Plan (WSRC, 1996d) to determine whether the FBRP source unit is the source of the contamination. Depending on the results of the groundwater assessment, three possible options have been recognized for addressing . the groundwater contamination: : 1) If no upgradient source is indicated, the contribution of the FBRP source unit is confirmed and a ROD for the FBRP groundwater will be pursued; 2). If a previously unrecognized upgradient source is identified, a new groundwater operable unit will be created which will undergo Remedial Investigation/Feasibility Study assessment; 3) If an existing upgradient groundwater operable unit is determined to be the source of the contamination, the boundaries of the existing operable unit will be modified to include the groundwater contamination in the FBRP area.

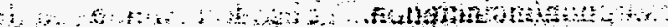
This source unit Statement of Basis/Proposed Plan provides for involvement of the community through a document review process and a public comment period. Public input will be documented in the Responsiveness Summary of the Record of Decision and RCRA epermit modification, as previously discussed. To submit written or oral commeht's, please refer to Section $\mathrm{II}$

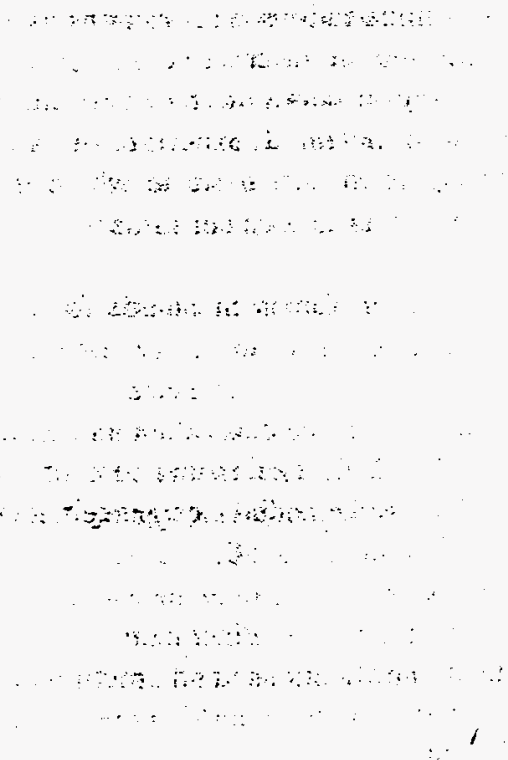




\section{REFERENCES}

DOE (U. S. Department of Energy), 1994. Public Involvement, A Plan for Savannah River Site. Savannah River Operations Office, Aiken South Carolina.

DOE, 1996. Savannah River Site Future Use Project Report, Stakeholder Recommendations for SRS Land and Facilities (U). Savannah River Operations Office, Aiken, South Carolina (January 1996).

EPA (U. S. Environmental Protection Agency), 1990. A Guide on Remedial Actions at Superfund Sites with PCB Contamination. Office of Emergency and Remedial Response. Directive 9355.4-01 FS (August 1990).

Federal Facility Agreement; 1993. Federal Facility Agreement for the Savannah River Site, Administrative Docket No. 89-05-FE, (Effective Date: August 16, 1993).

WSRC (Westinghouse Savannah River Company), 1994. Data Summary Report for the F-Area Buming/Rubble Pits. WSRC-TR-94-0293, Rev. 0, Westinghouse Savannah River Company, Aiken, South Carolina (1994).

WSRC, 1996a. RFI/RI Report for F-Area Burning/Rubble Pits (23I-F, 231-1F, and 231$2 F)(U)$. WSRC-RP-94-938, Rev. 1.1, Westinghouse Savannah River Company, Aiken, South Carolina (March 1996).

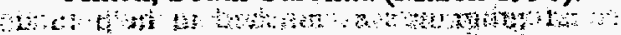

WSRC, $1996 \mathrm{~b}$ Baseline Risk Assessment for the $F$

Area Burning/Rubble Pits (U). WSRC-TR-94108, Rev. 1.2, Westinghouse Savannah River Company, Aiken, South Carolina (March 1996).

WSRC, 1996c. F-Area Burning/Rubble Pits (231F. 23I-IF, and 23I-2F) Corrective Measures Study/Feasibility Study (U). WSRC-RP-95660, Rev. 1.1, Westinghouse Savannah River Company, Aiken, South Carolina (June 1996).
WSRC, 1996d. Phase II. RCRA Facility Investigation/Remedial Investigation Plan for the F-Area Burning/Rubble Pits (231-F and $23 I-I F)$ and Rubble Pit $-(231-2 F)$ (U). WSRC-RP-90-486, Rev. 2.1, Westinghouse Savannah River Company, Aiken, South Carolina (May 1996).

\section{GLOSSARY}

Administrative Record File: A file that is maintained and contains all information used to make a decision on the selection of a response action under the Comprehensive. Environmental Response, Compensation \& Liability Act. This file is to be available for public review, and a copy is to be established at or near the Site, usually at one of the information repositories. Also a duplicate file is held in a central location, such as a regional or state office.

ARAR: Applicable, or Relevant and Appropriate Requirements: Refers to the federal and state requirements that a selected remedy will attain. These requirements may vary from site-to site.

Baseline Risk Assessment: Analysis of the potential adverse health effects (current or future) caused by hazardous substance release from a site in the absence of any actions to control or mitigate these releases.

Characterization: The compilation of all available data about the waste units to determine the rate and extent of contaminanit migration resulting form the waste site, and the concentration of any contaminants that may be present.

Comprehensive Environmental Response, Compensation and Liability Act (CERCLA), 1980: A Federal law passed in 1980 and modified in 1986 by the Superfund Amendments and Reauthorization Act. The Acts created a special tax that goes into a Trust Fund, commonly known as Superfund, to investigate and clean up abandoned or uncontrolled hazardous waste sites. 
Corrective Action: An EPA requirement to conduct remedial procedures under RCRA 3998(h) at a facility when there has been a release of hazardous waste or constituents into the environment. Corrective action may be required beyond the facility boundary and can be required regardless of when the waste was placed at the facility.

Exposure: Contact of an organism with a chemical or physical agent. Exposure is quantified as the amount of the agent available at the exchange boundaries of the organism (e.g., skin, lungs, digestive tract, etc.) and available for absorption.

Federal Facility Agreement (FFA): The legally binding agreement between regulatory agencies (EPA and SCDHEC) and regulated entities (DOE) that sets the standards and schedules for the comprehensive remediation of the SRS.

Media: A pathway through which contaminants are transferred. Five media by which contaminants may be transferred are groundwater, soil, surface water, sediments, and air.

National Prionities List (NPL): EPA's formal list of the nation's most serious uncontrolled or abandoned waste sites, identified for possible longterm remedial response, as established by CERCLA.

Operable Unit (OU): A discrete action taken as one part of an overall site cleanup. The term is also used in $\mathrm{EPA}$ guidance documents to refer to distinct geographic areas or media-specific units within a site. A number of operable units can be used in the course of a cleanup.

Operation and Maintenance (O\&M): Activities conducted at a site after a response action occurs to ensure that the cleanup and/or systems are functioning properly.

Overall Protection of Human Health and the Environment: The assessment against this criterion describes how the alternative, as a whole, achieves and maintains protection of human health and the environment.
Record Of Decision (ROD): A legal document that explains to the public which alternative will be used at a site/operable unit. The record of decision is based on information and technical analysis generated ' during the remedial investigation/feasibility study and consideration of public comments and community concerns.

Resource Conservation and Recovery Act (RCRA), 1976: A Federal law that established a regulatory system to track hazardous substances from their generation to disposal. The law requires safe and secure procedures to be used in treating, transporting, storing, and disposing of hazardous substances. RCRA is designed to prevent the creation of new, uncontrolled hazardous waste sites.

Responsiveness Summary: A summary of oral and/or written comments received during the proposed plan comment period and includes responses to those comments. The responsiveness summary is a key part of the ROD, highlighting community concerns.

Statement of Basis/Proposed Plan (SB/PP): A legal document that provides a brief analysis of remedial alternatives under consideration for the siteloperable unit and proposes the preferred alternative. This integrated RCRA/CERCLA document actively solicits public review and comment on all alternatives under consideration.

Superfund: The common name used for CERCLA; also referred to as the Trust Fund. The Superfund program was established to help fund cleanup of hazardous waste sites. It also allows for legal action to force those responsible for the sites to clean then up. 